as lecturer in horticulture at his old institution, now become the Faculty of Agriculture of the University of Nottingham. $\mathrm{He}$ was appointed head of the Depertment of Horticulture in 1953, after being acting head for two years. Since 1951, Hudson has been steadily developing his Department from that of a college concerned largely with certificates and diploma courses into a University Department of Horticulture. The depression in the horticultural industry which led to a fall in the number of candi. dates coming forward for degree courses made this a difficult period for the change, but Hudson successfully piloted his Department through, initiating at the same time a vigorous research school. The theme has been the influence of cultural practices on plant growth, and his contributions in two fields, namely, the control of soil moisture for glasshouse crops, and the influence of environment on the growth of biennial crops, have shown his excellent grasp of the fundamental principles involved, and the manner in which they may be applied to the benefit of the horticultural industry.

Dean of Graduate Studies at the Rockefeller Institute, New York: Dr. Frank Brink, jun.

Dr. Frank Brink, jun., has been appointed to the newly created office of dean of graduate studies at the Rockefeller Institute. Dr. Brink is a member and professor of the Institute, doing research work on biophysics. As dean, he will assist the president and the faculty committee on educational policies in the development of graduate education. The charter of the Rockefeller Institute was amended in Novem. ber 1954 so that the degrees of Ph.D. and M.D. could be granted with the authority of the Regents of the University of the State of New York. The Institute is now in its third year as a graduate university and has a limited enrolment of graduate students. Dr. Brink has been closely associated with the education programme of the Rockefeller Institute since its inception in 1954. Since 1956 he has served as secretary of the Trustees' Committee on Educational Policies under the chairmanship of Dr. Robert F. Loeb, of the Columbia University College of Physicians and Surgeons. Dr. Brink graduated from Pennsylvania State University in 1934. After a year of graduate work at the California Institute of Technology, where he received the degree of M.S., he began graduate work in biophysics at the Johnson Foundation at the University of Pennsylvania, where he received the degree of $\mathrm{Ph} . \mathrm{D}$. in 1940. He was later instructor in physiology at the Cornell University Medical College, assistant professor of biophysics at the University of Pennsylvania, and associate professor of biophysics at Johns Hopkins University. Since 1953 he has been at the Rockefeller Institute, where he has worked in the field of biophysics and neurophysiology in association with Dr. D. Bronk, the president. $\mathrm{He}$ is also a member of the board of editors of the Journal of General Physiology and is on the editorial board of the Journal of Cellular and Comparative Physiology and the advisory board of the Journal of Neurochemistry.

\section{Baghdad Pact Nuclear Centre}

THe Baghdad Nuclear Training Centre was established in 1956 by the member countries of the Baghdad Pact. It is at present concentrating on the practical applications of radioisotopes to the problems of Middle Eastern countries and is organizing intensive short courses in the uses and techniques of these materials. Two instructors each from Iraq, Iran, Pakistan and Turkey were trained at Harwell during 1956, and the United Kingdom also assisted by the gift of equipment and the loan of staff to supervise, teach and promote the development of the Nuclear Training Centre until local staff can assume responsibility. The first director of the centre, Mr. W. J. Whitehouse, was seconded from the U.K. Atomic Energy Authority in 1957 with four other members of the Authority's steff to prepare the Nuclear Training Centre, supervise the installation of British equipment there and to organize and assist in running the first course.

Mr. H. A. C. McKay of the Chemistry Division, Atomic Energy Research Establishment, Harwell, has now been appointed director of the Baghdad Pact Nuclear Centre from July 1958, in succession to Mr. W. J. Whitehouse. Mr. McKay, who was born in 1913, was educated at Balliol College, Oxford, and in 1935 was the Goldsmiths' Senior Scholar at the Institute for Theoretical Physics, Copenhagen. He was Beit Memorial Fellow at the Imperial College of Science and Technology, London, in 1937, and a demonstrator at King's College, London, in 1939. He served in the Royal Navy during the Second World War and in 1947 became a senior scientific officer in the Chemistry Division at Harwell, where he was appointed group leader of the Heavy Element Group in the Chemistry Division in 1954. He has specialized in solution chemistry.

\section{World List of Scientific Periodicals}

ONE result of the advances and developments in science and technology in recent years is reflected in the vast number of new scientific and technical journals that have appeared, together with an increase in the output of periodical publications throughout the world. This, combined with the fact that the third edition of the "World List of Scientific Periodicals" will soon become out of print, has led to active preparation for the issue of a fourth edition. In the new edition, brought up to date to include the new acientific and technical periodicals that have appeared in the past decade, the abbreviations of titles, where necessary, will be modified to conform with the International Standards Organization Recommendation $R 4$ of the International Code for the Abbreviation of Titles of Periodicals. The system recommended by the Royal Society for the transliteration of Russian, Serbian and Bulgarian for bibliographic purposes will also be adopted.

Since the location of the periodical publications available for reference in libraries is of the utmost importance to research, the librarians of the 247 libraries who contributed to the last edition are being requested to participate in the new edition of this important bibliographical work of reference. They are asked to send the titles of jourmals not appearing in the third edition, with particulars of their holdings, and amendments or corrections to the entries of their holdings of the 46,000 titles contrined in the last edition, to the Secretary, World List of Scientific Periodicals, of o the Zoological Society of London, Regent's Park, London, N.W.I, from which office further information may be obtained.

\section{Thermal Insulation of Houses}

THE Thermal Insulation (Dwellings) Bill which Mr. G. Nabarro introduced into the House of Com. mons on January 29, sponsored by members of both major political parties, extends the principle of the 